\title{
Pelaksanaan Pembelajaran Jarak Jauh Melalui Internet Pada Guru SD Bina Karya Bekasi
}

\author{
Muratin \\ Sekolah Tinggi Ilmu Ekonomi Tribuana \\ muratin892@gmail.com
}

\begin{abstract}
Learning outcomes are the abilities possessed by students after they receive the teaching and learning process carried out by educators. Assessment of learning outcomes has the aim of knowing the extent to which the learning process has been running. Learning outcomes can be seen through scores or grades after students take a test or test. Learning outcomes are categorized into three namely cognitive, affective, psychomotor. The learning outcomes of each student are different because they are influenced by many factors, including the school environment and family environment. The aims of this study were to: (1) explain the influence of the school environment on student learning outcomes in Islamic subjects at SD Bina Karya, (2) explain the influence of the family environment on student learning outcomes in Islamic subjects at SD Bina Karya, (3) explain the influence of the school environment and family environment on student learning outcomes in Islamic subjects at SD Bina Karya.
\end{abstract}

Keywords: School Environment, Family Environment, Learning Outcomes, Distance Learning

\begin{abstract}
Abstrak
Hasil belajar adalah kemampuan-kemampuan yang dimiliki oleh siswa setelah ia menerima proses belajar mengajar yang dilakukan oleh pendidik. Penilaian hasil belajar memiliki tujuan untuk mengetahui sejauh mana proses pembelajaran yang telah berjalan. Hasil belajar dapat dilihat melalui skor atau nilai setelah siswa mengerjakan suatu tes atau ulangan. Hasil belajar dikategorikan menjadi tiga yaitu kognitif, afektif, psikomotoris. Hasil belajar setiap siswa berbeda karena dipengaruhi oleh banyak faktor yaitu diantaranya lingkungan sekolah dan lingkungan keluarga. Tujuan penelitian ini adalah untuk: (1) Menjelaskan pengaruh lingkungan sekolah terhadap hasil belajar siswa mata pelajaran Agama Islam di SD Bina Karya, (2) Menjelaskan pengaruh lingkungan keluarga terhadap hasil belajar siswa mata pelajaran Agama Islam di SD Bina Karya, (3) Menjelaskan pengaruh lingkugan sekolah dan lingkungan keluarga terhadap hasil belajar siswa mata pelajaran Agama Islam di SD Bina Karya.
\end{abstract}

Kata kunci: Lingkungan Sekolah, Lingkungan Keluarga, Hasil belajar, Pembelajaran Jarak Jauh

\section{PENDAHULUAN}

Pendidikan merupakan bagian integral dalam pembangunan, karena pendidikan merupakan wahana untuk meningkatkan dan mengembangkan sumber daya manusia yang sangat diperlukan dalam proses pembangunan.
Pembangunan diarahkan dan bertujuan untuk mengembangkan sumber daya manusia yang berkualitas dan pembangunan ekonomi, yang satu dengan yang lain saling berkaitan dan berlangsung bersamaan. Dalam rangka 
meningkatkan kualitas sumberdaya manusia diperlukan pendidikan yang bermutu dan dikelola secara profesional. Pendidikan nasional adalah usaha secara sadar dan terencana untuk mewujudkan suasana belajar dan proses pembelajaran agar murid secara efektif mengembangkan potensi dirinya untuk memiliki potensi spiritual, keagamaan, pengendalian diri, kebiasaan, kecerdasan dan ketrampilan yang diperlukan bagi dirinya, masyarakat, bangsa dan negara (UU nomor 20 tahun 2003).

Guru PJJ SD Bina Karya berasal dari konsorsium guru-guru yang ada di Sekolah Dasar Harapan Indonesia. Kemampuan guru dalam menggunakan internet sebagai media pembelajaran jarak jauh, guru sudah mahir menggunakan internet, tetapi masih ada beberapa yang masih mengalami kesulitan dalam pengoperasiannya. Untuk guru yang masih mengalami kesulitan, pihak pengelola PJJ memberi fasilitas seorang teknisi yang akan membantu para guru jika menemukan kesulitan dalam mengoperasikan internet. Walaupun demikian proses pembelajaran ini masih mengalami kendala yang berasal dari guru yaitu kesibukan guru membuat guru tidak bisa untuk terus menerus duduk didepan internet, sehingga kadang-kadang guru terlambat membalas inisiasi dari siswa.
Pihak pengelola sudah mengatasi masalah tersebut adalah pihak pengelola membuat jadwal tutorial online, dimana pada waktu tutorial online berlangsung guru dan siswa dapat berinteraksi secara online.

Salah satu upaya meningkatkan mutu pendidikan nasional yaitu adanya guru yang berkualitas, profesional dan berpengetahuan. Guru, tidak hanya sebagai pengajar, namun guru juga mendidik, membimbing, mengarahkan, melatih, menilai dan mengevaluasi murid. Dalam menjalankan tugasnya sebagai agen pembelajaran, maka guru diharapkan memiliki empat kompetensi dasar, yaitu kompetensi paedagogi, kompetensi sosial, kompetensi kepribadian dan kompetensi profesional. Guru yang profesional adalah guru yang menguasai materi pembelajaran, menguasai kelas dan mengendalikan perilaku anak didik, menjadi teladan, membangun kebersamaan, menghidupkan suasana belajar dan menjadi manusia pembelajar (learning person).

Virus corona telah masuke ke Indonesia sejak awal tahun 2020, sehingga pemerintah harus mengeluarkan banyak kebijakan agar terputusnya mata rantai penyebaran virus. Salah satu kebijakan yang dikeluarkan adalah ditutupnya sekolah, sekolah dan Lembaga Pendidikan. Proses mengajar 
dan belajar diarahkan kepada sistem pembelajaran Jarak jauh secara Daring. Dalam proses pembelajaran Jarak Jauh, guru dan murid dapat memanfaatkan teknologi informasi berupa gadget dan juga leptop yang memiliki jaringan internet.

Guru yang datang dari dunia pradigital kesulitan untuk membangun komunikasi yang efektif dengan murid untuk melangsungkan belajar mengajar secara Daring. Kebiasaan dan cara mereka belajar pun tentu sangat berbeda dengan kebiasaan dan cara para guru dan orang tua mereka belajar. Pada dasarnya pendidikan jarak jauh adalah jenis pendidikan dimana murid berjarak jauh dari guru, sehingga pendidikan tidak dapat dilakukan secara tatap muka dan penyampaian pesan dari guru kepada murid harus dilakukan melalui media (Setijadi, 2005:1). Karena pesan disampaikan melalui media, maka murid diharapkan dapat belajar mandiri. Belajar mandiri bukan berarti belajar sendiri, melainkan belajar dengan tanggung jawab sendiri.

Proses pembelajaran Jarak Jauh sendiri menyediakan interaksi antara murid dan guru untuk mengadakan interaksi (diskusi, tanya jawab) secara tatap muka atau jarak jauh (melalui surat, telepon atau komputer). Akan tetapi tutorial ini sangat jarang dilakukan sehingga murid harus belajar secara mandiri. Salah satu media yang dapat dimanfaatkan untuk pendidikan jarak jauh adalah internet. Internet merupakan perpaduan antara teknologi komputer, teknologi audio-visual, teknologi komunikasi dan teknologi pembelajaran itu sendiri, dan sifatnya sudah menyerupai bentuk pembelajaran langsung (direct instruction) yang dapat melayani banyak pengguna (user) dalam waktu yang bersamaan namun tetap melayani individu muriddalam kerangka pelaksanaan pembelajaran yang individual.

Dalam mengikuti kegiatan pembelajaran melalui internet seharusnya guru memiliki kemampuan untuk berpikir secara terbuka, berkomunikasi melalui lisan, memotivasi dan mendisiplinkan diri. Jika menemui masalah, kesediaan dan ketaatan untuk belajar secara teratur, memenuhi tuntutan minimal yang dipersyaratkan setiap program atau materi pembelajaran, berpikir kritis dan mengambil keputusan merupakan bagian dari proses belajar, mengakses internet, memberikan tanggapan, belajar dengan kualitas tinggi dapat terjadi tanpa harus melalui kelas tradisional (Siahaan, 2005:35). 
Murid yang mengikuti pembelajaran jarak jauh diharapkan dapat mengikuti kegiatan belajar di kelas maya selama 5-7 hari setiap minggunya, bekerjasama dengan murid lainnya dalam mengerjakan tugas (proyek), menggunakan teknologi secara baik, memenuhi standar minimal sebagaimana yang ditetapkan oleh lembaga, menyelesaikan tugas-tugas tepat waktu menikmati komunikasi tulis. Suatu sistem pendidikan jarak jauh secara umum akan sukses apabila di dalamnya melibatkan interaksi maksimal antara guru dan siswanya, antara murid dengan berbagai fasilitas pendidikan dan interaksi antara murid dengan murid serta melibatkan pola pembelajaran yang aktif di dalam interaksi itu.

Murid atau murid yang mengikuti pembelajaran jarak jauh diharapkan dapat mengikuti kegiatan belajar di kelas maya selama 5-7 hari setiap minggunya, bekerjasama dengan murid lainnya dalam mengerjakan tugas (proyek), menggunakan teknologi secara baik, memenuhi standar minimal sebagaimana yang ditetapkan oleh lembaga, menyelesaikan tugas-tugas tepat waktu menikmati komunikasi tulis. Suatu sistem pendidikan jarak jauh secara umum akan sukses apabila di dalamnya melibatkan interaksi maksimal antara guru dan muridnya, antara murid dengan berbagai fasilitas pendidikan dan interaksi antara murid dengan murid serta melibatkan pola pembelajaran yang aktif di dalam interaksi itu.

Hipotesis dari penelitian ini akan menunjukan seberapa besar tingkat Gap dengan adanya perbedaan antara Pembelajaran Jarak Jauh yang sudah dilaksanakan. Oleh itu peneliti mempunyai rumusan masalah sebagai berikut, "Apakah terdapat hubungan serta dampak Lingkungan Sekolah serta Lingkungan Keluarga terhadap hasil belajar melalui Pembelajaran Jarak Jauh atau biasa disebut dengan PJJ, dimana ada kelebihan dan kekurangan dari pembelajaran tersebut". Siswa juga dapat menilai dan memberikan sanggahnya atau bahkan keluhan pada saat pandemi Covid-19 ini. Sebagaimana kita tahu, bahwa PJJ sangat berperan penting dengan Lingkungan Sekolah terhadap Guru dan Lingkungan Rumah dengan peran orang tua membimbing anakanaknya untuk dapat bersekolah, sesuai dengan kewajiban sekolah 9 tahun pada anak Usia Dini.

\section{METODOLOGI PENELITIAN}

Tahapan-tahapan yang akan dilaksanakan dalam penelitian ini adalah sebagai berikut, Penelitian pra lapangan merupakan proses persiapan yang harus 
sebelum penelitian dilakukan. Selanjutnya, peneliti menggunakan teknik pekerjaan lapangan. Dimana, peneiliti memasuki langsung terjun ke lapangan. Setelah semua persiapan baik intern maupun ekstern terpenuhi, peneliti dapat mulai memasuki lapangan penelitian secara proporsional. Setelah itu, Peneiliti mengumpulkan data, secara langsung melakukan wawancara, dan dokumentasi maupun observasi. Wawancara dilakukan secara bebas artinya tidak terikat alur jabatan, sesuai dengan situasi, kondisi dan kebutuhan peneliti. Begitu juga saat melakukan observasi dan dokumentasi.

\section{Peneilti menggunakan Etika}

penelitian, Dalam penelitian kualitatif peran peneliti sangat besar. Etika dalam penelitian harus benar-benar diperhatikan dengan demikian perasaan empati dan kekeluargaan dapat terjalin dengan baik dengan tetap konsisten pada cara penelitian sebagai berikut, 1). Menyusun rancangan penelitian yang disebut proposal penelitian. Pada tahap awal, tema penelitian lebih dulu diajukan pada kepada Guru Kelas I dan Guru Kelas II untuk mendapatkan persetujuan, dan kemudian diajukan dalam bentuk proposal penelitian dan diserahkan kepada Guru Kelas I dan Guru Kelas II untuk mendapatkan bimbingan dan persetujuan. 2) Menjajaki dan menilai keadaan lapangan. Kegiatan ini selain dilakukan pada saat memilih lapangan, juga akan dilaksanakan pada saat peneliti memasuki lapangan penelitian. 3) Memilih lapangan penelitian Berkaitan dengan tema penelitian yaitu Kendala Pembelajaran Jarak Jauh dalam Memanfaatkan Internet, maka lembaga yang dipilih sebagai lapangan penelitian adalah Program Pendidikan Jarak Jauh SD Hapan Indonesia.

Peneliti juga mempunyai Etika dalam melakukan penelitian, ini termasuk etika sebabagai seorang peneliti, hal-hal tersebut harus dilaksanakan sebagai peneiliti, tahapan pertama adalah mengurus perijinan, pada tahap awal perijinan dilakukan secara lisan. Setelahnya, konsep dan form perijinan penelitian disetujui secara formal kepada lembaga yang menaungi penelitian, yaitu SD Bina Karya. Lalu peneliti memilih dan memanfaatkan informan penelitian, informan dipilih dengan cara purposive sample (sampel bertujuan) dan dimanfaatkan sesuai dengan tujuan penelitian. Cara ini dipilih dengan tujuan untuk menjaring sebanyak mungkin informasi dari berbagai sumber dan menggali informasi yang akan menjadi dasar dari rancangan dan teori yang muncul. Selain itu pada teknik 
sampel bertujuan, sampel tidak ditentukan terlebih dahulu, sampel dapat ditentukan ketika penelitian berlangsung. Informan penelitian berasal dari pengelola, guru dan siswa PJJ SD Bina Karya. Terakhir, Menyiapkan kelengkapan penelitian, Perlengkapan penelitian yang dipersiapkan antara lain alat tulis, alat perekam, kamera dan garis besar materi wawancara.

\section{HASIL DAN PEMBAHASAN}

Sistem penyelenggaraan program PJJ di SD Bina Karya merupakan sistem yang baru dilaksanakan disekolah tersebut untuk memenuhi kebutuhan Pendidikan dalam keadaan pandemi yang sedang terjadi di Indonesia saat ini. Melalui pendidikan jarak jauh ini menerapkan sistem PJJ residensial, yang mempersyaratkan siswa untuk melakukan sekolah tutorial online yang dilaksanakan selama 5 (lima) bulan.

Adapun subjek yang dimintai keterangan sebanyak 11 orang, terdiri dari atas koordinator dan teknisi PJJ yang mengetahui banyak tentang Pelaksanaan pembelajaran jarak jauh ini kemudian 2 dari guru kelas selaku pelaksana dan dari siswa yang bersangkutan sebanyak 7 orang. Berikut adalah uraian data yang peneliti peroleh selama penelitian.

Berdasarkan pada hasil penelitian yang telah diperoleh, peneliti akan menguraikan data secara deskriptif. Pada penelitian ini digunakan beberapa singkatan sebagai kode untuk mempermudah proses pencocokan data yang terdapat di dalam paparan data dengan data yang tertulis pada lampiran:

1. Lamp. Informan, yaitu lampiran wawancara pada informan penelitian yang berkedudukan sebagai koordinator, staf administrasi dan guru PJJ, Lamp. Informan I merupakan hasil wawancara dengan koordintor pengelola, Lamp. Informan II adalah hasil wawancara dengan teknisi, sedangkan Lamp. Informan III dan IV adalah hasil wawancara dengan guru I dan guru II.

2. Lamp. Siswa, yaitu lampiran wawancara pada informan penelitian yang berkedudukan sebagai siswa.

3. Pt, yaitu pertemuan yang terjadi antara peneliti dengan informan penelitian

4. Dt, yaitu pengambilan data yang disesuaikan dengan pedoman wawancara

5. b, yaitu nomor baris yang termuat di dalam kolom lampiran hasil wawancara pada masing-masing informan penelitian.

Singkatan tersebut berarti bahwa, data yang terdapat pada paparan data 
penelitian dapat dilihat pada halaman lampiran. Sesuai dengan hasil penelitian yang telah diperoleh peneliti dari informan, berikut ini dikemukakan beberapa data temuan di lapangan yang diperoleh dari wawancara dan observasi.

Berikut adalah hasil wawancara dengan koordinator pengelola, mengenai persiapan yang dilakukan untuk proses pembelajaran jarak jauh Siswa SD Bina Karya. Persiapan pelaksanaan pembelajaranya, persiapannya sebelum online dan face to face, untuk siswa baru itu tentunya dibekali dengan kemudian pengenalan akademik PJJ seperti apa sistemnya, akademik di SD Bina Karya bagaimana sistemnya, guruya dan juga masalah kesiswaan di SD Bina Karya itu seperti apa, (Lamp. Informan I/Dt.1/Pt.5/b.65-70).

Penjelasan di atas didukung oleh penuturan guru. Di bawah ini adalah hasil wawancara dengan guru PJJ mengenai persiapan yang dilakukan untuk proses pembelajaran jarak jauh SISWA SD Bina Karya. Sosialisasi melalui center-center yang didirikan oleh kantor kabupaten dinas pendidikan disana kan ada center ICT yang dikelola oleh pemerintah daerah dan awal kuliah diberikan pembekalan mengenai ICT dan materi selama 1 bulan dan setelah itu siswa menunggu inisiasi dari SD Bina
Karya dikirimkan melalui email, (Lamp. Informan III/Dt.1/Pt.6/b.13-18).

Dari hasil wawancara di atas mengenai persiapan pelaksanaan pembelajaran jarak jauh, peneliti menyimpulkan bahwa persiapan yang dilakukan untuk proses pembelajaran jarak jauh yaitu selama 1 bulan dilaksanakan proses pembelajaran face to face, dalam proses face to face siswa diberi bekal berupa pelatihan ICT selama 3 hari mengenai pengenalan komputer, internet, email dan pengenalan akademik kemudian setelah itu baru dilakukan pembelajaran jarak jauh. Sedangkan hasil wawancara dengan koordinator pengelola mengenai prosedur dan seleksi siswa adalah sebagai berikut: Teknisi PJJ juga menjelaskan bagaimana prosedur PJJ. Berikut adalah penjelasannya:

PJJ siswa menggunakan gawai atau leptop yang tersambung ke Internet, kegiatan PJJ akan dilakukan sesuai dengan jadwal sekolah biasanya. Hal tersebut didukung oleh pernyataan guru dan siswa yang menjelaskan bahwa tanpa adanya gadged atau leptop siswa tidak dapat melakukan aktivitas PJJ. Hasil observasi yang peneliti peroleh dari pedoman akademik siswa PJJ Siswa SD Bina Karya, dijelaskan bahwa kesanggupan untuk mengikuti aktivitas belajar dan mengajar dengan 
memanfaatkan internet, email atau web dengan segala konsekuensinya. Data hasil wawancara mengenai motivasi siswa mengikuti program PJJ, peneliti dapat menyimpulkan bahwa motivasi siswa mengikuti program ini untuk mendapat pengetahuan dan pengalaman.

Sedangkan hasil wawancara dengan siswa mengenai kemampuan mereka dalam mengakses internet adalah sebagai berikut, "Ketika aku mulai pertama kali bingung, aku belum bisa mengoperasikan internet. Jangankan internet, komputer pun aku belum bisa. Teman-teman semua di sini belajar bagaimana mengoperasikan internet. Pertama kali datang kita membuat email, email digunakan untuk berinteraksi dengan guru maupun siswa. Karena ada internet kita nggak perlu datang langsung atau bertemu langsung dengan guru".

Penjelasan mengenai kemampuan mereka dalam mengakses internet didukung oleh penuturan dua orang siswa lainnya. Hasil wawancaranya adalah sebagai berikut, "Pada awalnya saya belum pernah mengenal komputer, jadi itu karena belum.., istilahnya belum pernah megang, jadi itu hal yang baru bagi kami. Pertama memang gragaplah istilahnya. Karena sekarang sudah terbiasa, setiap ada tugas kan harus dipaksakan, karena dipaksakan kan harus belajar, walaupun tadinya gragap, alhamdulillah sekarang sudah bisa mengakses, baik men- download, maupun mengirim email". Imbuh, Siswa ke 1. "Awalnya sama sekali belum bisa mbak. Menyentuh komputer pun belum pernah mbak, tapi setelah mengenal internet, jadi keterusan mbak, buka situssitus yang ada. Itu yang bikin saya jadi hobi dengan internet mbak. Sekarang hampir tiap hari saya membuka internet. Selain itu di rumah juga ada labtop dan HP, tinggal disambung kan sudah bisa internetan mbak", Imbuh, Siswa ke 2.

Data hasil wawancara di atas dapat ditarik kesimpulan bahwa pada awal memasuki aktivitas belajar dan mengajar banyak siswa yang belum bisa mengoperasikan internet, tetapi karena dalam proses pembelajaran jarak jauh siswa harus bisa mengoperasikan internet, mereka terus berusaha dan akhirnya bisa karena terbiasa. Selanjutnya, pada bagian dibawah ini adalah hasil wawancara dengan koordiantor pengelola mengenai kesiapan guru dalam mengunakan internet untuk PJJ. "Jadi dulu waktu kita koordinasi, menyatakan pendapat bahwa sistem yang kita gunakan tidak seperti UT pure, artinya hanya guru, tidak ada 
onlinenya. Gurunya juga kita bekali dengan SKT (satuan kegiatan tutorial). Kita kan sudah SIKADU, saya positif thinking beliau kan sudah terbiasa memasukkan nilai/entri nilai, istilahnya sudah tidak asing lagi dengan komputer, selain itu beliau juga sudah banyak yang sudah acesor, masalah internet, email itu bukan merupakan kendala, walaupun ada 1,2 yang masih sering bertanya dengan pak Hendra, jadi kami kan menggunakan jasa pak Hendra sebagai teknisi. Jadi guru-guru yang kesulitan pertama kali mau mengirimkan atau mencocokkan email siswa atau email beliau itu kami fasilitasi, tetapi sebagian besar tidak asing lagi dengan internet", Imbuh Koordinator pengelola PJJ.

Penjelasan di atas didukung oleh penuturan dua orang guru. Berikut adalah hasil wawancaranya, "Untuk sekarang ini ya guru sudah mahir menggunakan internet, artinya kemampuanya sekitar $75 \%$ kalau yang mahir sekali ya baru 1 atau 2 orang lah tidak banyak, dan siswanya sekitar 6075\% lah, (Lamp. Informan III/Dt.1/Pt.5/b.45-48). Ya mestinya seperti itu, tapi untuk temen-temen yang sepuh-sepuh masih susah masih perlu bantuan untuk mengakses internet tapi untuk yang masih muda-muda saya kira lumayan bisa”, Imbuh, 2 orang Guru.
Hasil wawancara diatas mengenai kemampuan guru dalam menggunakan internet sebagai media pembelajaran jarak jauh, peneliti menyimpulkan bahwa guru sudah mahir menggunakan internet, tetapi masih ada beberapa yang masih mengalami kesulitan dalam pengoperasiannya. Untuk guru yang masih mengalami kesulitan, pihak pengelola PJJ memfasilitasi mereka dengan menggunakan jasa seorang teknisi yang bisa membantu guru mengatasi kesulitan tersebut.

Berikut ini adalah data hasil wawancara dengan koordinator pengelola dan teknisi PJJ mengenai proses pelaksanaan pembelajaran yang berlangsung pada program PJJ. "Proses pembelajarannya tadi Hylite, face to face 8 kali pertemuan dengan gurunya kemudian dilanjutkan dengan online, jadi tugas yang harus di- download kemudian dikirimkan kembali, jadi mereka punya email masing- masing guru. Pada waktu pembekalan mereka sudah dibekali materi tentang membuat email, chatting, kemudian mengirim kembali. Jadi face to face-nya itu 8 kali pertemuan dalam satu bulan tiap semesternya, online 5 kali tugas kemudian ujian, untuk kuliah berikutnya mereka datang untuk ujian dan langsung 
ke semester berikutnya," Penjelasan di atas didukung oleh penuturan teknisi PJJ. Berikut hasil wawancaranya: "Untuk proses pembelajarannya ada 4 tahap yaitu yang pertama adalah pembelajaran internet (ICT), yang kedua face to face yaitu pembelajaran tatap muka dan ujian dari guru, yang ketiga website based learning, dalam prosesnya ada inisiasi, dan setiap mata kuliah ada 5 inisiasi. Guru punya hak membuat tugas diluar tugas inisiasi”, Imbuh, salah seorang dari Teknisi PJJ.

Hasil observasi yang peneliti peroleh dalam pedoman akademik siswa PJJ SD Bina Karya, dijelaskan bahwa ada 2 jenis kegiatan pembelajaran yaitu belajar mandiri dan belajar terbimbing. Belajar mandiri meliputi: (1) mengikuti program pembekalan belajar mandiri, (2) Mempelajari bahan ajar yang berbentuk hybrid, yaitu berbentuk bahan ajar cetak (printed), audio visual, dan bahan ajar berbasis web, (3) Mengerjakan Tugas Tutorial (TT) online, (4) Melaksanakan praktik dan praktikum secara mandiri. Sedangkan belajar terbimbing meliputi :

(1) Interaksi melalui media, (2) Tutorial, (3) Kelompok belajar (KB).

Hasil observasi dan wawancara di atas, peneliti menyimpulkan bahwa ada 2 tahap kegiatan pembelajaran dalam proses PJJ yaitu tahap belajar mandiri yang meliputi (1) mengikuti program pembekalan belajar mandiri,

Mempelajari bahan ajar yang berbentuk hybrid, yaitu berbentuk bahan ajar cetak (printed), audio visual, dan bahan ajar berbasis web, (3) Mengerjakan Tugas Tutorial (TT) online, (4) Melaksanakan praktik dan praktikum secara mandiri. Tahap belajar mandiri dilakukan pada saat Face to face dan online. Sedangkan tahap kedua yaitu belajar terbimbing, belajar terbimbing merupakan layanan bantuan belajar yang diberikan perguruan tinggi penyelenggara kepada siswa.

Berikutnya, ini adalah hasil wawancara dengan guru mengenai pelaksanaan proses pembelajaran jarak jauh selama ini. "Kalau saya sebagai guru memberikan nilai tambah yang positif sekali, jadi dengan PJJ ini siswa itu harus menguasai masalah teknologi informasinya yaitu dengan mengoperasionalkan internet, harus bisa membuat email, bisa menjawab email, bisa chatting dsb, dan disamping itu sangat efesien dan efektif karena baik guru dan siswa tidak harus datang setiap hari ke kampus", imbuh salah satu seorqng guru, "Sesuai dengan perkembangan teknologi ya, memang saat ini guru-guru mau tidak mau harus menguasai apa namanya teknologi 
informasi yaitu internet, sehingga pembelajaran seperti ini memang inovasi yang bagus lah" Imbuh salah satu siswa juga menuturkan hal yang sama. Berikut hasil wawancara dengan dua orang siswa mengenai pelaksanaan proses pembelajaran jarak jauh selama ini. "Kalau menurut saya pelaksanaan face to face positif, sudah sesuai dengan jadwal, dalam artian guru dan siswa antusias untuk belajar", imbuhnya. "Pada waktu online Feedback dari guru udah bagus, kebanyakan memberi balasan untuk kami, walaupun kadangkala ada 1,2 yang tidak seluruhnya dibalas". "Cukup baik, cukup lancar nanti setelah aktivitas belajar dan mengajar tatap muka seperti ini kemudian kami ditempat masingmasing kita menunggu nanti ada inisiasi biasanya 1 mata kuliah dalam 1 semester ada 5 inisiasi kemudian kami mengerjakan tugas kemudian kami mengirim jawabanya lewat email setelah itu ada respon dari guru apa yang kurang dan memberikan masukan dari guru", perkataan, Siswi ke 2. Berdasarkan hasil wawancara di atas mengenai pelaksanaan pembelajaran jarak jauh, peneliti dapat menyimpulkan bahwa proses pembelajaran jarak jauh berjalan lancar dan cukup efektif sesuai dengan perkembangan teknologi. Hal ini pun dirasakan oleh para siswanya yang merasa puas akan pelaksanaan proses pembelajaran.

Di bawah ini adalah hasil wawancara dengan siswa mengenai penyampaian materi dalam proses pembelajaran jarak jauh. "Penyampaian materi bagus juga, pada waktu face to face kita kan punya modul sebelum ada pelajaran kita belajar dulu dari modul, terus besoknya kalau ada pertemuan kita tanya mungkin ada bagian yang kita kurang tahu, trus kita sharing, diskusi presentasi, kemudian ditanggapi, jadi hiduplah suasananya mbak", "Materi yang disampaikan lewat internet sama dengan yang dari modul, kalau yang saya tangkap itu gini, sebagian modul disampaikan lewat face to face syukur bisa habis, kita kan waktunya terbatas yang lainnya disampaikan online melalui internet. Tugas online dari modul juga, tapi bisa juga suruh cari di internet. Kita kan ngirim tugas inisiasi ya mbak,kan tugasnya dibalas oleh guru, mungkin dari guru ada tugas tambahan suruh cari apa?", kata siswa di SD Bina Karya.

Penjelasan di atas didukung oleh penuturan siswa lainnya. Berikut adalah hasil wawancaranya: "Untuk materi diawali dengan face toface selama 3-4 minggu, untuk online-nya tugas-tugas. Di SD Bina Karya ini kita face to face sama guru sampai 1 modul selesai. Cuma 
untuk lebih jelasnya kita baca di rumah sambil mengerjakan tugas dari guru". "Materi pada waktu face to face dan online, dua-duanya mudah dipahami. Face to face adalah keterangan awal kita mendapatkan ilmu, sedangkan untuk tugas online berarti kita menjajagi diri kita sejauh mana kita memahami apa yang disampaikan guru, walaupun untuk kejelasannya kita harus baca-baca buku."

Penjelasan di atas didukung oleh data hasil dokumentasi yang peneliti temukan dalam Pedoman Akademik PJJ di SD Bina Karya, Evaluasi hasil belajar siswa dilakukan melalui berbagai jenis penilaian, penilaian tersebut meliputi:

1. Tes di Akhir Tutorial Tatap Muka, tes ini merupakan ujian yang diberikan pada akhir tutorial tatap muka untuk setiap mata kuliah pada masa residensial.

2. Tugas dan Partisipasi Tutorial Online. Tugas tutorial online merupakan tugas yang diberikan guru untuk menilai penguasaan siswa atas materi mata kuliah secara utuh.

3. Ujian Akhir Semester (UAS), UAS merupakan ujian yang harus diikuti oleh siswa di akhir aktivitas belajar dan mengajar yang dimaksudkan untuk mengukur kemampuan siswa dalam pencapaian kompetensi satu mata kuliah. Bentuk ujian dapat berupa uraian, tes objektif, atau campuran antara uraian dan tes objektif.

4. Praktikum, merupakan unjuk kerja siswa dalam rangka penerapan dan pengintegrasian pengetahuan dan keterampilan yang telah dipunyai siswa sebelumnya secara nyata dalam praktik, membuktian dan atau penemuan suatu konsep secara ilmiah (scientific inquiry). Praktikum dilaksanakan pada masa residensial atau secara mandiri bekerja sama dengan mitra.

Karakteristik pendidikan jarak jauh adalah (1) adanya keterpisahan yang mendekati permanen antara tenaga pengajar dari peserta didik selama program pendidikan, (2) adanya keterpisahan yang mendekati permanen antara seorang peserta didik dengan peserta didik lain selama program pendidikan, (3) ada suatu institusi yang mengelola program pendidikannya,(4) pemanfaatan sarana komunikasi baik mekanis maupun elektronis untuk menyampaikan bahan belajar, penyediaan sarana komunikasi dua arah sehingga peserta didik dapat mengambil inisiatif dialog dan mengambil manfaatnya (Keegan, 1984 dalam Warsita 2007: 13).

Selanjutnya, program pendidikan 
jarak jauh, interaksi antara siswa dengan gurunya ditandai dengan keterpisahan jarak secara fisik. Pembelajaran dilaksanakan dengan mediasi bahan ajar, baik bahan ajar cetak maupun non- cetak terutama dengan menggunakan ICT. Salah satu konsideran dalam PTJJ adalah jumlah pertemuan tatap muka antara siswa dengan guru tidak sebanyak yang dilaksanakan dengan sistem aktivitas belajar dan mengajar tatap muka. Untuk itu, agar penyelenggaraan program ini berjalan dengan baik, maka keterbatasan pertemuan tadi diganti dengan interaksi melalui penggunaan media komputer (jaringan) dalam bentuk internet. Dalam hal ini, internet tidak saja digunakan untuk sarana interaksi antara siswa dengan guru, akan tetapi internet juga digunakan untuk mengemas bahan ajar yang akan disampaikan kepada siswa.

\section{KESIMPULAN}

Kesimpulan Peneliti dalam penulisan ini ada beberapa mengenai Eksperimen yang dilakukan oleh guru dengan objek siswa dan pengendalian pada pengelola PJJ, adalah sebagai berikut:

1. Perawalan dan persiapan dari guru adalah faktor kunci untuk PJJ yang akan datang, sehingga pihak sekolah perlu menyiapkan atau mentraining lebih lanjut kesigapan dari pada guru dan pengelola dari PJJ tersebut.
Namun, dengan adanya kondisi Covid yang mendadak ini, maka setidaknya guru diberikan sertifikasi untuk dapat mengajar dengan keadaan-keadaan dan resiko yang akan terjadi sehingga semua bisa siap dan lebih matang lagi. Proses pembelajaran PJJ meliputi 2 tahap, yaitu tahap belajar mandiri yang meliputi (1) mengikuti program pembekalan belajar mandiri, (2) Mempelajari bahan ajar yang berbentuk hybrid, yaitu berbentuk bahan ajar cetak (printed), audio visual, dan bahan ajar berbasis web, (3) Mengerjakan Tugas Tutorial (TT) online, (4) Melaksanakan praktik dan praktikum secara mandiri. Tahap belajar mandiri dilakukan pada saat Face to face dan online. Sedangkan tahap kedua yaitu belajar terbimbing, belajar terbimbing merupakan layanan bantuan belajar yang diberikan perguruan tinggi penyelenggara kepada siswa.

2. Dari teori di atas dapat disimpulkam bahwa program PJJ Siswa Sekolah Dasar Harapan Indonesia mempunyai karakteristik yang sesuai dengan teori diatas. Hal ini dapat dilihat dari Resikonya, (1) terpisahnya siswa dan guru selama proses pembelajaran 
onlline berlangsung, (2) pada waktu program pembelajaran beralangsung siswa berada di tempat yanng berbeda, dalam hal ini siswa berada di daerah masing-masing, (3) program ini dikelola oleh sebuah institusi yaitu Sekolah Dasar Harapan Indonesia, (4) penyampaian bahan belajarnya juga dilakukan melalui media internet, (5) memanfaatkan sarana komunikasi dua arah yang menhubungkan siswa dan guru dalam hal ini yang digunakan adalah internet.

2. Karena kesiapan guru dan siswa dalam memahami pembelajaran jarak jauh berbasis internet ini harus dimiliki agar dalam pelaksanaannya berjalan dengan kondusif walaupun secara geografis memisahkan mereka dalam proses belajar mengajar, maka dalam pelaksanaan pembelajaran jarak jauh melalui internet perlu dipertimbangkan mengenai sumber daya manusia terutama bagi para pengajar. Apakah mereka sudah siap dalam melaksanakan pembelajaran berbasis teknologi internet ini dengan baik.

3. Dalam proses pelaksanaannya disediakan layanan online yang ada di ICT dinas tingkat kabupaten, tetapi kenyataannya pemanfaatannya belum maksimal. Maka peran dinas
Pendidikan dalam mendukung program PJJ siswa perlu dioptimalkan.

4. Evaluasi hasil belajar siswa dilakukan melalui berbagai jenis penilaian, penilaian tersebut meliputi: (a) Tes di Akhir Tutorial Tatap Muka, tes ini merupakan ujian yang diberikan pada akhir tutorial tatap muka untuk setiap mata kuliah pada masa residensial; (b) Tugas dan Partisipasi Tutorial Online. Tugas tutorial online merupakan tugas yang diberikan guru untuk menilai penguasaan siswa atas materi mata kuliah secara utuh; (c) Ujian Akhir Semester (UAS), Bentuk ujian dapat berupa uraian, tes objektif, atau campuran antara uraian dan tes objektif; (d) Praktikum yang dilaksanakan pada masa residensial atau secara mandiri bekerja sama dengan mitra.

\section{REFERENCES}

Arikunto, Suharsimi. 2002. Prsedur penelitian Suatu Pendekatan Praktek. Jakarta: PT Adi Mahasatya.

Darsono, Max. 2000. Belajar dan Pembelajaran. Semarang: CV. IKIP Semarang Perss. E-learning Suatu Paradigma

Pendidikan Era Digital. http://www.kecoak- elektronik.net. (25 April 2008).

Hamalik, Oemar.2001. Kurikulum dan pembelajaran. Jakarta : Bumi Aksara. Hamzah. 2006. 


\section{Perencanaan Pembelajaran.} Jakarta: Bumi Aksara.

Harjanto. $1997 . \quad$ Perencanaan pengajaran. Jakarta: Rineka Cipta.

Ibrahim, Nurdin. 2005.'ICT Untuk Pendidikan Terbuka Jarak Jauh". Jurnal Teknodik.Juni 2005. Nomor 16: 5-18. Jakarta: Pustekkom Depdiknas.

Internet:Pengertian,Sejarah,danFas ilitas-fasilitasnya.

ibrariy.usu.ac.id/modules,php?op=m odlooad\&name $=$ download $\&$ file $=$ ind ex\&req=getit\&lid=1536. (diakses pada tanggal 28 November 2007).

Marpaung, N. N. (2021a). PENGARUH

KUALITAS PELAYANAN DAN

HARGA TERHADAP

KEPUTUSAN PEMBELIAN AIR

MINUM ISI ULANG "BIRU” DI

JL. JEMBATAN 5 PONDOK

TIMUR - KOTA BEKASI.

PARAMETER, 5(1), 12-25.

https://doi.org/10.37751/parameter.v $5 \mathrm{i} 1.136$

Marpaung, N. N. (2021b). Pengaruh

Manajemen Tenaga Pendidik

Terhadap Prestasi Belajar Peserta

Didik di SD Harapan Indonesia Kota

Bekasi. PARAMETER, 6(1), 12-23.

https://doi.org/10.37751/parameter.v $6 \mathrm{i} 1.158$

Moeleong, Lexy. 2004. Metode Penelitian Kualitatif (edisi revisi). Bandung: PT. Remaja Rosdakarya.

Patmanthara, Syaad.2007. "Pembelajaran Melalui Internet di Perguruan Tinggi". Jurnal Teknodik. April 2007. Nomor 20: 57-72. Jakarta: Pustekkom depdiknas.

Sagala, Syaiful. 2006. Konsep dan makna pembelajaran untuk membantu memecahkan problematika belajar dan mengajar. Bandung: Alfabeta.
Setijadi.2005. Buku pedoman pendidikan Jarak Jauh. Jakarta: Sekolah Dasar terbuka.

Siahaan, Sudirman. 2005.'Pemanfaatan Teknologi dalam Penyelenggaraan Pendidikan Jarak Jauh". Jurnal Teknodik. Juni 2005. Nomor 16: 2944. Jakarta: Pustekkom Depdiknas.

Sugandi, Ahmad, et all. 2006. Teori Pembelajaran. Semarang: SD BINA KARYA Perss.

Warsita. 2007. "Peranan TIK Dalam penyelenggaraan PJJ". Jurnal Teknodik. April 2007. Nomor 20: 9 41. Jakarta: Pustekkom depdiknas.

Yani, Ivo. 2007. Penerapan E-Learning Dalam Pembelajaran. http://www.bpplsp- reg-1.go.id/elearning/index.php?do $=$ news \&id=13. (Diakses pada tanggal 6 September 2008). 